\title{
Elution Buffers for Human Enteric Viruses in Vegetables with Applications to Norovirus Detection
}

\author{
Aerie Moon, Jaehyun Ahn', and Weon Sang Choi* \\ Department of Biotechnology, College of Science and Technology, Dongguk University-Gyeongju, \\ Gyeongju, Gyeongbuk, Korea \\ ${ }^{1}$ Ourhome Food Research Institute, Seongnam, Gyeonggi, Korea \\ (Received July 8, 2013/Revised August 13, 2013/Accepted October 16, 2013)
}

\begin{abstract}
The efficient elution of viruses from contaminated food is a critical step for its detection. In this study, conditions optimal for enteric viral recovery from three leafy vegetables (cabbage, lettuce, sesame leaf) and three root vegetables (carrot, onion, mooli) were analyzed to find common buffers (statistically not different) applicable to the leafy and root vegetables. Viral recovery varied depending on the food matrices or elution buffers. Buffer solutions containing $0.25 \mathrm{M}$ threonine $/ 0.3 \mathrm{M} \mathrm{NaCl}(\mathrm{pH} 9.5)$ or $0.25 \mathrm{M}$ glycine $/ 0.14 \mathrm{M} \mathrm{NaCl}$ ( $\mathrm{pH} 9.5$ ) could efficiently recover poliovirus from five out of six vegetables. The threonine buffer was applied to one leafy vegetable (sesame) and one root vegetable (carrot) for genogroup II norovirus (NoV) detection. The detection sensitivity was significantly higher from the leafy vegetable compared to the root vegetable. The use of these common elution buffers should facilitate the detection of low levels of NoV and other enteric viruses in a wide range of vegetables.
\end{abstract}

Key words: poliovirus, norovirus, elution, detection

\section{Introduction}

The role of food in the transmission of viral gastroenteritis has been increasingly recognized, including foods such as vegetables and mollusks. The transmission of enteric viruses typically occurs through foods via a fecal-oral route. Enteric viruses can persist in the environment for long periods and are highly resistant to disinfectants, heat, pressure, and temperature $^{1)}$. In addition, a few infectious viral particles are sufficient for inducing gastroenteritis ${ }^{2)}$.

Fresh vegetables may be exposed to fecal contamination from numerous methods: irrigation with contaminated water, fertilization with inadequately composed manure, or handling by infected persons with poor hygiene ${ }^{3)}$. Salad vegetables are usually consumed raw after being washed with water; however, enteric viruses can survive this minimal treatment ${ }^{4,5)}$. Although procedures are available for the detection of enteric viruses (including norovirus (NoV)) in vegetables ${ }^{3-9}$ ), one of the most critical requirements for effective detection is the elution of viruses from vegetables. Once viral particles are dried on the surface of food or absorbed into the food,

\footnotetext{
*Correspondence to: Weon Sang Choi, Department of Biotechnology, College of Science and Technology, Dongguk UniversityGyeongju, Gyeongju, Gyeongbuk, Korea

Tel: 82-54-770-2227, Fax: 82-54-770-2386

E-mail: weonsang@dongguk.ac.kr
}

elution is difficult. The recovery can vary enormously depending on the food matrices and elution buffers used. Various kinds of buffers are used alone or combined for the elution step; however, elution buffers applicable to all kinds of vegetables have not been optimized. The CDC has recently developed a basic list of food commodities for outbreak analysis (http://www.cdc.gov/foodborneburden/attribution. $\mathrm{html}$ ), with foods categorized according to the nature of the food source. In contrast, it is necessary to categorize foods in ways helpful for suggesting the elution buffers and methods required for the sensitive detection of enteric viruses in fresh vegetables. As sesame leaves, carrot, lettuce, onion, cabbage, and mooli are considerably consumed raw after or minimally cooked in many restaurants and homes in Korea, these vegetables represent a potential hazard for consumers. Therefore, it will be very useful to develop an efficient viral elution procedure for these vegetables according to the food source.

Poliovirus, a member of the Picornaviridae family, is a non-enveloped icosahedral virus containing a single positivestrand RNA genome. Poliovirus is frequently used as a surrogate, due to its similar size and morphology to $\mathrm{NoV}^{3,8-13)}$, and the plaque assay is more convenient for the evaluation of viral recovery than RT-PCR. In this report, we describe common elution buffers for detecting enteric viruses in leafy (cabbage, lettuce, sesame leaf) and root (carrot, onion, mooli) vegetables and its application for detecting NoV in one leafy and one root vegetable. 


\section{Materials and Methods}

\section{Cell culture and viruses}

The stock of the Sabin strain of poliovirus type 1 used in this study was derived from transfection of the full-length viral cDNA to COS-1 cells, and poliovirus titer was determined by plaque assays using HeLa cells ${ }^{9)}$. The NoV GII used in this study was obtained from the Division of Enteric and Hepatitis Viruses at the National Institute of Health, (Seoul, Korea). The titer of NoV GII stock was 128 RT-PCR units/ml. The NoV titer in RT-PCR units was determined by endpoint dilutions. RT-PCR was performed in a MyCycler (Bio-Rad, USA). One RT-PCR unit was defined as the last dilution from which NoV RNA could be amplified and visualized from gel electrophoresis (Mupid, Takara) with ethidium bromide ${ }^{9,14)}$.

\section{Reagents}

One -step RT-PCR premix and PCR reagents were obtained from the Intron Biotechnology (Seongnam, Korea). Primers were purchased from Genotech (Daejeon, Korea). All chemicals, unless otherwise stated, were purchased from SigmaAldrich (St. Louis, USA).

\section{Inoculation of vegetables}

Sesame leaves, carrots, onions, and mooli were purchased at a local supermarket (Gyeongju, Korea) and tested negative for poliovirus and NoV through with PCR. An individual carrot (25 g), onion (25 g), and mooli (25 g) were cut into pieces (about $2 \times 3 \mathrm{~cm}$ ), rinsed in water, and allowed to dry for $1 \mathrm{hr}$ in a laminar flow chamber. Individual sesame leaves $(10 \mathrm{~g})$ were also cut into pieces (about $1 \times 1 \mathrm{~cm}$ ) and were washed and dried in the same manner. A portion (10$100 \mu \mathrm{L}$ ) of a known plaque-forming unit (PFU) of poliovirus $\left(10^{5}-10^{6} \mathrm{PFU}\right)$ or NoV (10-250 RT-PCR units) was spread over the vegetable surface and allowed to dry for $3 \mathrm{hr}$ in a laminar flow chamber.

\section{Viral recovery in the poliovirus plaque assay}

Virus inoculated on the vegetables was eluted with elution buffer $(150 \mathrm{~mL})$ in a centrifuge tube and placed into a shaking incubator $\left(20-23^{\circ} \mathrm{C}, 150 \mathrm{rpm}\right)$ for $3 \mathrm{hr}$. There was very little difference in viral recovery between 3 and 16 incubations (data not shown). The aqueous phase was decanted into sterile $250 \mathrm{~mL}$ centrifuge bottles and five $\mathrm{mL}$ was used for the plaque assay after filtering with a syringe filter $(0.45 \mu \mathrm{m}$ porosity; Pall Corporation, USA). All experiments were performed at least three times independently and recovery were calculated based on the titer of the added poliovirus stock (set at $100 \%$ ) counted on every trial.

\section{Viral recovery and RNA extraction for RT-PCR}

10-25 $\mathrm{g}$ of virus-inoculated vegetables were eluted with buffers, and the suspension was further purified to remove RT-PCR inhibitors. An equal volume of chloroform:isoamyl alcohol (24:1) was added to the suspension, vigorously shaken for $20 \mathrm{~min}$, and centrifuged at $11,000 \times \mathrm{g}$ for $20 \mathrm{~min}$ at $4^{\circ} \mathrm{C}$. After collecting the aqueous layer, polyethylene glycol (PEG) 8000 and $\mathrm{NaCl}$ were added to achieve a final concentration of $11 \% \mathrm{PEG}$ and $0.3 \mathrm{M} \mathrm{NaCl}$. The viral suspensions were stored at $4^{\circ} \mathrm{C}$ for $3 \mathrm{hr}$ to allow precipitation of the viral particles. Viruses were concentrated by centrifugation at $11,000 \times \mathrm{g}$ for $20 \mathrm{~min}$ and the pellets were resuspended in 1-3 $\mathrm{mL}$ of diethyl pyrocarbonate (DEPC)-treated water. The QIAmp Viral RNA mini kit (Qiagen, USA) was used to extract RNA from the concentrated viruses according to the manufacturer's instructions with minor modification. Instead of $140 \mu \mathrm{L}$ of viral concentrates, $280 \mu \mathrm{L}$ was used for RNA extraction.

\section{RT-PCR and RT-PCR combined with nested PCR}

Reaction conditions and the primers (DG172, DG173, DG213, DG214, GII-F1M, GII-R1M, and GII-F3M) for RTPCR, or RT-PCR combined with nested PCR, have previously been described ${ }^{9,11,15)}$. The 340 and 524 bp RT-PCR products for GII NoV and poliovirus, respectively, and the 310 and 506 bp RT-PCR (combined with nested PCR) products for GII and poliovirus, respectively, were separated by electrophoresis (Mupid, Takara) on 1.5\% agarose gels containing ethidium bromide and visualized with ultraviolet (UV) light.

\section{Statistical analysis}

Results obtained were subjected to $F$-test using SPSS version 18. A $P$ value of 0.05 was considered to represent the minimum level of significance.

\section{Results and Discussion}

\section{Poliovirus recovery from vegetables by elution}

The elution of viruses from contaminated food is a critical step for efficient viral detection. Elution efficiency can vary according to the food matrices, isoelectric point of viral surface proteins, electrostatic interactions between viruses and food surface, different stabilities of viruses under drying conditions, smoothness of the food surface, and viral resistance at low $\mathrm{pH}$ on the food surface ${ }^{3,10,16-20)}$. Beef extract ${ }^{4,21)}$, amino acid buffer ${ }^{3,8,22)}$, Tris buffer ${ }^{23)}$, amino acid-NaCl buffer $^{3,9,14,19,24)}$, Tris-glycine buffer ${ }^{3,25)}$, or a combination of these buffers ${ }^{6,12,19,26)}$ were examined for their ability to elute virus from produce in several studies. In this study, several buffers including PBS, beef extract, glycine buffers, and threonine buffers were compared for viral recovery from one 
Table 1. Recoveries of poliovirus from vegetables using different elution buffers ${ }^{\mathrm{a}}$ (Unit: \%)

\begin{tabular}{|c|c|c|c|c|c|c|c|c|}
\hline $\begin{array}{c}\text { Buffer } \\
\text { numbers }\end{array}$ & Elution buffers & $\mathrm{pH}$ & cabbage $^{\mathrm{b}}$ & lettuce $^{b}$ & sesame leaves & carrot & onion & mooli \\
\hline 1 & PBS & 7.4 & $5.7 \pm 0.9$ & $5.0 \pm 1.6$ & $3.7 \pm 1.4$ & $17.1 \pm 1.7$ & $11.8 \pm 7.3$ & $33.4 \pm 9.3$ \\
\hline 2 & $3 \%$ beef extract & 9.5 & $7.4 \pm 1.4$ & $4.8 \pm 1.3$ & $5.5 \pm 0.6$ & $71.5 \pm 2.1$ & $7.3 \pm 1.9$ & $58.3 \pm 15.7$ \\
\hline 3 & $0.05 \mathrm{M}$ Gly- $0.14 \mathrm{M} \mathrm{NaCl}$ & 7.5 & $46.6 \pm 40.3$ & $7.8 \pm 0.8$ & $10.3 \pm 3.5$ & $25.2 \pm 6.1$ & $7.5 \pm 4.7$ & $12.9 \pm 5.1$ \\
\hline 4 & $0.05 \mathrm{M}$ Gly- $0.14 \mathrm{M} \mathrm{NaCl}$ & 9.5 & $73.4 \pm 15.1$ & $42.2 \pm 7.5$ & $40.2 \pm 16.9$ & $49.9 \pm 15.19$ & $\mathrm{~N} / \mathrm{D}^{\mathrm{c}}$ & $\mathrm{N} / \mathrm{D}$ \\
\hline 5 & $0.05 \mathrm{M}$ Gly- $0.3 \mathrm{M} \mathrm{NaCl}$ & 7.5 & $37.6 \pm 21.9$ & $5.8 \pm 0.8$ & $23.8 \pm 7.9$ & $\mathrm{~N} / \mathrm{D}$ & $\mathrm{N} / \mathrm{D}$ & $\mathrm{N} / \mathrm{D}$ \\
\hline 6 & $0.05 \mathrm{M}$ Gly- $0.3 \mathrm{M} \mathrm{NaCl}$ & 9.5 & $50.8 \pm 28.9$ & $48.5 \pm 11.2$ & $57.5 \pm 30.4$ & $\mathrm{~N} / \mathrm{D}$ & $10.3 \pm 4.3$ & $78.2 \pm 7.9$ \\
\hline 7 & $0.25 \mathrm{M}$ Gly- $0.14 \mathrm{M} \mathrm{NaCl}$ & 7.5 & $50.1 \pm 21.0$ & $8.1 \pm 0.9$ & $31.3 \pm 14.9$ & $49.3 \pm 24.4$ & $\mathrm{~N} / \mathrm{D}$ & $30.6 \pm 16.0$ \\
\hline 8 & $0.25 \mathrm{M}$ Gly- $0.14 \mathrm{M} \mathrm{NaCl}$ & 9.5 & $61.9 \pm 5.5$ & $46.0 \pm 19.1$ & $44.6 \pm 13.2$ & $54.3 \pm 16.1$ & $25.6 \pm 5.5$ & $55.4 \pm 11.2$ \\
\hline 9 & $0.25 \mathrm{M}$ Gly- $0.3 \mathrm{M} \mathrm{NaCl}$ & 7.5 & $61.1 \pm 41.0$ & $27.3 \pm 16.2$ & $45.7 \pm 22.2$ & N/D & N/D & $41.8 \pm 16.1$ \\
\hline 10 & $0.25 \mathrm{M}$ Gly- $0.3 \mathrm{M} \mathrm{NaCl}$ & 9.5 & $68.3 \pm 43.9$ & $34.9 \pm 19.6$ & $30.9 \pm 12.8$ & $\mathrm{~N} / \mathrm{D}$ & $\mathrm{N} / \mathrm{D}$ & $\mathrm{N} / \mathrm{D}$ \\
\hline 11 & $0.05 \mathrm{M}$ Thr- $0.14 \mathrm{M} \mathrm{NaCl}$ & 7.5 & $20.0 \pm 4.5$ & $8.3 \pm 2.2$ & $9.7 \pm 2.6$ & $11.6 \pm 6.2$ & $6.6 \pm 2.3$ & $37.7 \pm 7.9$ \\
\hline 12 & $0.05 \mathrm{M}$ Thr- $0.14 \mathrm{M} \mathrm{NaCl}$ & 9.5 & $54.2 \pm 24.3$ & $42.6 \pm 19.2$ & $33.6 \pm 12.8$ & $93.3 \pm 9.5$ & $8.5 \pm 5.6$ & $43.1 \pm 10.1$ \\
\hline 13 & $0.05 \mathrm{M}$ Thr- $0.3 \mathrm{M} \mathrm{NaCl}$ & 7.5 & $59.0 \pm 7.9$ & $29.2 \pm 17.8$ & $17.0 \pm 7.7$ & N/D & $\mathrm{N} / \mathrm{D}$ & $53.1 \pm 3.0$ \\
\hline 14 & $0.05 \mathrm{M}$ Thr- $0.3 \mathrm{M} \mathrm{NaCl}$ & 9.5 & $82.6 \pm 13.3$ & $50.3 \pm 13.2$ & $33.6 \pm 13.5$ & $51.1 \pm 8.1$ & $25.5 \pm 3.2$ & N/D \\
\hline 15 & $0.25 \mathrm{M}$ Thr- $0.14 \mathrm{M} \mathrm{NaCl}$ & 7.5 & $82.3 \pm 8.1$ & $53.3 \pm 11.3$ & $33.3 \pm 11.5$ & $53.0 \pm 20.7$ & N/D & $29.1 \pm 10.0$ \\
\hline 16 & $0.25 \mathrm{M}$ Thr- $0.14 \mathrm{M} \mathrm{NaCl}$ & 9.5 & $77.2 \pm 11.9$ & $46.1 \pm 23.7$ & $28.4 \pm 8.4$ & $43.3 \pm 26.3$ & N/D & $47.9 \pm 15.4$ \\
\hline 17 & $0.25 \mathrm{M}$ Thr- $0.3 \mathrm{M} \mathrm{NaCl}$ & 7.5 & $89.1 \pm 13.3$ & $56.2 \pm 13.3$ & $37.1 \pm 13.0$ & $\mathrm{~N} / \mathrm{D}$ & N/D & $35.1 \pm 6.2$ \\
\hline 18 & $0.25 \mathrm{M} \mathrm{Thr}-0.3 \mathrm{M} \mathrm{NaCl}$ & 9.5 & $90.0 \pm 13.3$ & $62.7 \pm 19.7$ & $44.7 \pm 8.6$ & $80.3 \pm 10.1$ & $35.2 \pm 5.0$ & $33.5 \pm 9.3$ \\
\hline
\end{tabular}

a: recovery was calculated based on the titer of the added poliovirus stock (set as 100\%) counted on every trial (average \pm standard deviation)

b: modified data from Moon et al. 2009

c: N/D; not tested

Table 2. Selected buffers for the efficient elution of poliovirus from vegetables

\begin{tabular}{ccccccc}
\hline & \multicolumn{3}{c}{ Leafy vegetables } & \multicolumn{3}{c}{ Root vegetables } \\
\cline { 2 - 7 } & cabbage & lettuce & sesame leaf & carrot & onion & mooli \\
\hline Selected buffer & $4,8,9,10,14,15,16,17,18$ & $4,6,8,12,14,15,16,17,18$ & $4,6,8,9,18$ & $2,12,18$ & $8,14,18$ & $2,6,8,13$ \\
numbers from & $P=0.1688$ & $P=0.3728$ & $P=0.4449$ & $P=0.0706$ & $P=0.0802$ & $P=0.0674$ \\
Table $1^{\mathrm{a}}$ & $\geq 61.1 \%^{\mathrm{b}}$ & $\geq 42.2 \%^{\mathrm{b}}$ & $\geq 40.2 \%^{\mathrm{b}}$ & $\geq 71.5 \%^{\mathrm{b}}$ & $\geq 25.5 \%^{\mathrm{b}}$ & $\geq 53.1 \%^{\mathrm{b}}$ \\
\hline \multirow{2}{*}{ Top 3 buffers } & $14,17,18$ & $15,17,18$ & $6,9,18$ & $2,12,18$ & $8,14,18$ & $2,6,8$ \\
& $P=0.5710$ & $P=0.5472$ & $P=0.4379$ & $P=0.0706$ & $P=0.0802$ & $P=0.1437$ \\
\hline
\end{tabular}

a: Buffers tested were numbered at Table 1 . High recovery buffers, statistically not different, were selected.

b: Minimum recovery of the selected buffers within group is shown.

leafy vegetable (sesame leaf) and three root vegetables (carrot, onion, mooli) (Table 1). The recovery data for the leafy vegetables (cabbage and lettuce) from Moon et al.9) were analyzed together with the data of this study for finding common elution buffers. The efficacy of a buffer widely varied according to the food matrices. All the tested buffers only eluted limited amounts of virus from onions (6.6$35.2 \%$ ). Phosphate buffered saline (PBS), previously used to elute viruses from raw vegetables ${ }^{3,5,27-29)}$, was generally inefficient, compared with other buffers, at recovering poliovirus. In our study, only $3.7-33.4 \%$ of polioviruses were recovered with PBS ( $\mathrm{pH}$ 7.4) from sesame leaf, carrot, onion and mooli. In the previous study, $5.0-5.7 \%$ of polioviruses were eluted from cabbage and lettuce ${ }^{9)}$. Beef extract $(3 \%, \mathrm{pH}$
9.5) was highly efficient for elution from two root vegetables (71.5\% in carrot, $58.3 \%$ in moolis), whereas only $4.8-7.4 \%$ was recovered from sesame leaf (Table 1). Beef extract was also not efficient from two leafy vegetables (cabbage, lettuce) in the previous report ${ }^{9}$. To find common buffers (statistically not different) applicable to all the vegetables tested, buffers that had a good and consistent elution capacity were selected from Table 1 (summarized in Table 2). Buffers at $\mathrm{pH} 9.5$ generally had a tendency to recover more poliovirus particles from food surfaces, probably due to protection against the acidic $\mathrm{pH}$ on the food surface ${ }^{26}$. In addition, a better recovery was generally observed when glycine or threonine buffers with a concentration of $0.25 \mathrm{M}$ were used (compared to buffers with a concentration of $0.05 \mathrm{M}$ ). Two buffers, $0.25 \mathrm{M}$ 
glycine and $0.14 \mathrm{M} \mathrm{NaCl}(\mathrm{pH} 9.5)$ (\#8), or $0.25 \mathrm{M}$ threonine and $0.3 \mathrm{M} \mathrm{NaCl}(\mathrm{pH} \mathrm{9.5)} \mathrm{( \# 18)} \mathrm{could} \mathrm{efficiently} \mathrm{recover}$ poliovirus from five out of six vegetables (Table 2; three leafy and two root vegetables). Based on the results, we deduced that buffers containing $0.25 \mathrm{M}$ threonine $/ 0.3 \mathrm{M}$ $\mathrm{NaCl}(\mathrm{pH} 9.5)(\# 18)$ or $0.25 \mathrm{M}$ glycine $/ 0.14 \mathrm{M} \mathrm{NaCl}(\mathrm{pH}$ 9.5) (\#8) are good common viral detection buffers applicable to leafy and root vegetables.

\section{Detection sensitivity}

The sensitivity of NoV GII detection by RT-PCR combined with nested PCR was 0.2 RT-PCR units, which was determined using serial dilutions of stool samples (data not shown). The level of NoV GII detection for the procedure was determined by inoculating serially-diluted NoV GII on sesame leaves (leafy vegetables) or carrots (root vegetables), processing with $0.25 \mathrm{M}$ threonine $/ 0.3 \mathrm{M} \mathrm{NaCl}(\mathrm{pH} 9.5)$, and then examining final RNA concentrates by RT-PCR combined with semi-nested PCR (NoV GII). Poliovirus (10,000 pfu) was used as a positive control to monitor proper processing. With the initial seeding levels, 100 RT-PCR units of GII NoV/10 g sesame leaves were detected, whereas 50 RT-PCR units of GII NoV/25 g carrot were detected (Fig. 1). No sample inhibition was observed in any of the samples tested, as dilution prior to amplification didn't improve viral detection $^{14,30)}$ (data not shown). Detection limits can widely differ according to the analytical method used (i.e., RT-PCR, RT-PCR with nested PCR, or real-time PCR), sample amount tested, virus strains, and the primer sets used ${ }^{8}$. Therefore, direct comparison of analyses is difficult due to variations in food matrices and the methods employed ${ }^{26}$. The detection limits obtained with our procedure are roughly similar to the detection limits previously reported (10-1,500 RT-PCR units/ $6-50 \mathrm{~g}$ food) $)^{6,14,19,25,30,31)}$, with the exception of work that reported as little as 1 RT-PCRU of NoV in green onions ${ }^{7}$. Nevertheless, that work was not validated for other food
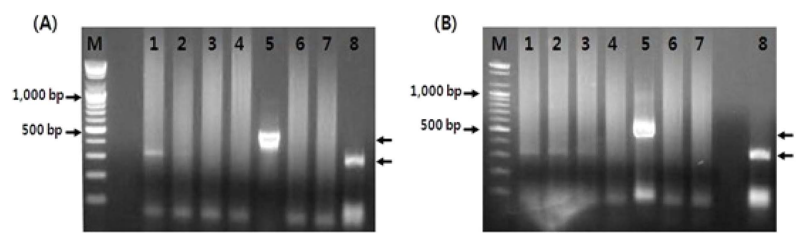

Fig. 1. Detection of noroviruses in sesame leaves and carrots by RT-PCR combined with semi-nested PCR. (A) $10 \mathrm{~g}$ of sesame leaves or (B) $25 \mathrm{~g}$ of carrots were artificially contaminated with GII NoV. Lane M, molecular size marker (100 bp ladder); lane 1, 250 RT-PCR units of NoV; lane 2, 100 RT-PCR units of NoV; lane 3, 50 RT-PCR units of NoV; lane 4, 10 RT-PCR units of NoV; lane 5, 10,000 PFU of poliovirus as a positive control to monitor proper processing; lanes $6 \& 7$, negative control; lane 8, positive control (GII NoV cDNA was amplified by PCR). matrices. The number of NoV genome copies per RT-PCR unit has been estimated to be as low as $10-50^{32,33)}$. Therefore, about 500-5,000 GII NoV particles, detected by RT-combined with semi-nested PCR, can be detected in 10-25 g of leafy or root vegetables with this procedure.

In summary, 18 buffers were compared for eluting viruses in vegetables. Our results suggest that buffers with $0.25 \mathrm{M}$ threonine $/ 0.3 \mathrm{M} \mathrm{NaCl}(\mathrm{pH} 9.5)$ or $0.25 \mathrm{M}$ glycine $/ 0.14 \mathrm{M}$ $\mathrm{NaCl}(\mathrm{pH}$ 9.5) can serve as common buffers useful for eluting viruses in leafy and root vegetables. The use of these common elution buffers should facilitate the detection of low levels of $\mathrm{NoV}$ and other kinds of enteric viruses found in a wide range of vegetables.

\section{요 약}

오염된 식품으로부터 바이러스를 효과적으로 검출하기 위해서는 식품에 부착된 바이러스를 효과적으로 elute시키 는 것이 결정적으로 중요하다. 본 연구에서는 채소류에 공 통적으로 적용할 수 있는 elution용액을 찾기 위해 폴리오 바이러스를 인위적으로 오염시킨 1가지 엽채류 (깻잎) 와 3 가지 근채류 (당근, 양파, 무) 로부터 바이러스 회수율을 조사한 후, 최적의 바이러스 회수조건을 찾기 위해 기보 고된 상추와 양배추의 회수율을 함께 분석하였다. 바이러 스의 회수율은 식품의 matrix와 사용된 elution용액의 종 류에 따라 차이가 컸으나 $0.25 \mathrm{M}$ threonine $/ 0.3 \mathrm{M} \mathrm{NaCl}(\mathrm{pH}$ $9.5)$ 또는 $0.25 \mathrm{M}$ glycine $/ 0.14 \mathrm{M} \mathrm{NaCl}(\mathrm{pH}$ 9.5)을 사용하 였을 때 6 가지 채소 중 5 가지로부터 폴리오바이러스를 효 과적으로 elute 할 수 있었다. $0.25 \mathrm{M}$ threonine $/ 0.3 \mathrm{M} \mathrm{NaCl}$ $(\mathrm{pH}$ 9.5)를 노로바이러스 검출에 적용해 본 결과 근채류인 당근보다 엽채류인 깻잎으로부터 노로바이러스 GII를 더 잘 검출할 수 있었다. 이 같은 공통 elution용액을 사용할 경우 다양한 종류의 채소류에 오염된 노로바이러스를 포 함한 소화기바이러스의 검출을 용이하게 해 줄 것이다.

\section{Acknowledgment}

This work was partially supported by a grant from the Korean Food \& Drug Administration in 2008. This work was also supported through the Dongguk UniversityGyeongju Research Fund (2013).

\section{References}

1. Patel, M.M., Hall, A.J., Vinjé, J. and Parashar, U.D.: Noroviruses: A comprehensive review. J. Clin. Virol. 44, 1-8 (2009).

2. Teunis, P.F., Moe, C.L., Liu, P., Miller, S.E., Lindesmith, L., Baric, R.S., Le Pendu, J. and Calderon, R.L.: Norwalk virus: how infectious is it? J. Medical Virol. 80, 1468-1476 (2008). 
3. Dubois, E., Hennechart, C., Deboosére, N., Merle, G., Legeay, O., Burger, C., Le Calvé, M., Lombard, B., Ferré, V. and Traoré, O.: Intra-laboratory validation of a concentration adapted for the enumeration of infectious F-specific DNA coliphage, enterovirus and hepatitis A virus from inoculated leaves of salad vegetables. Int. J. Food Microbiol. 108, 164171 (2006).

4. Croci, L., De Medici, D., Scalfaro, C., Fiore, A. and Toti, L.: The survival of Hepatitis A virus in fresh produce. Int. J. Food Microbiol. 73, 29-34 (2002).

5. Bidawid, S., Farber, J.M. and Sattar, S.A.: Rapid concentration and detection of hepatitis A virus from lettuce and strawberries. J. Virol. Methods 88, 175-185 (2000).

6. Butot, S., Putallaz, T. and Sánchez, G.: Procedure for rapid concentration and detection of enteric viruses from berries and vegetables. Appl. Environ. Microbiol. 73, 186-192 (2007).

7. Guévremont, E., Brassard, J., Houde, A., Simard, C. and Trottier, Y.: Development of an extraction and concentration procedure and comparison of RT-PCR primer systems for the detection of hepatitis A virus and norovirus GII in green onions. J. Virol. Methods 134, 130-135 (2006).

8. Le Guyader, F.S., Schultz, A., Haugarreau, L., Croci, L., Manula, L., Duizer, E., Lodder-Verchoor, F., von Bonsdorff, C., Suffredin, E., van der Poel, W.M.M., Reymundo, R. and Koopmans, M.: Round-robin comparison of the methods for the detection of human enteric viruses in lettuce. J. Food Protec. 67, 2315-2319 (2004).

9. Moon, A., Hwang, I. and Choi, W.S.: Development of a virus elution and concentration procedure for detecting norovirus in cabbage and lettuce. Food Sci. Biotechnol. 18, 407-412 (2009).

10. Kurdziel, A.S., Wilkinson, N., Langton, S. and Cook, N.: Survival of poliovirus on soft fruit and salad vegetables. $J$. Food Prot. 64, 706-709 (2001).

11. Ha, S., Woo, G., Hwang, I. and Choi, W.S.: Development of a virus elution and concentration procedure for detecting norovirus in oysters. Food Sci. Biotechnol. 18, 1150-1154 (2009).

12. Dubois, E., Agier, C., Traoré, O., Hennechart, C., Merle, G., Cruciére, C. and Laveran, H.: Modified concentration method for the detection of enteric viruses on fruits and vegetables by reverse transcriptase-polymerase chain reaction or cell culture. J. Food Protect. 65, 1962-1969 (2002).

13. Love, D.C., Casteel, M.J., Meschke, J.S. and Sobsey, M.D.: Methods for recovery of hepatitis A virus (HAV) and other viruses from processed foods and detection of HAV by nested RT-PCR and TaqMan RT-PCR. Int J. Food Microbiol. 126, 221-226 (2008).

14. Sair, A.I., D'Souza, D.H., Moe, C.L. and Jaykus, L.A.: Improved detection of human enteric viruses in foods by RTPCR. J. Virol. Methods 100, 57-69 (2002).

15. Jee, Y.: Establishment of detection method for norovirus Part II. Technical report. Korean Food \& Drug Administration, Seoul, Korea pp. 20-23 (2006).

16. Gerba, C.P.: Applied and theoretical aspects of virus adsorption to surfaces. Advances in Appl. Microbiol. 30, 133-168 (1984).
17. Konowalchuk, J. and Speirs, J.I.: Survival of enteric viruses on fresh fruit. J. Milk Food Technol. 38, 600 (1975).

18. Abad, F.X., Pinto, R.M. and Bosch, A.: Survival of enteric viruses on environmental formites. Appl. Environ. Microbiol. 60, 3704-3710 (1994).

19. Vega, E., Smith, J., Garland, J., Matos, A. and Pillaii, S.D.: Variability of virus attachment patterns to butterhead lettuce. J. Food Prot. 68, 2112-2117 (2005).

20. Baert, L., Uyttendaele, M. and Debevere, J.: Evaluation of viral extraction methods on a broad range of ready-to-eat foods with conventional and real-time RT-PCR for norovirus GII detection. Int. J. Food Microbiol. 123, 101-108 (2008).

21. Kim, H., Kwak, I., Hwang, I. and Ko, G.: Optimization of methods for detecting norovirus on various fruit. J. Virol. Methods 153, 104-110 (2008).

22. Summa, M., von Bonsdorff, C. and Maunula, L.: Evaluation of four virus recovery methods for detecting norovirus on fresh lettuce, sliced ham, and frozen raspberries. J. Virol. Methods 183, 154-160 (2012).

23. Morales-Rayas, R., Wolffs, P.F.G. and Griffiths, M.W.: Simultaneous separation and detection of hepatitis A virus and norovirus in produce. Int. J. Food Microbiol. 139, 48-55 (2010).

24. Papafragkou, E., Plante, M., Mattison, K., Bidawid, S., Karthikeyan, K., Farber, J.M. and Jaykus, L.: Rapid and sensitive detection of hepatitis A virus in representative food matrices. J. Virol. Methods 147, 177-187 (2008).

25. Dubois, E., Hennechart, C., Ghislaine, M., Burger, C., Hmila, N., Ruelle, S., perelle, S. and Ferrc, V.: Detection and quantification by real-time RT-PCR of hepatitis A virus from inoculated tap waters, salad vegetables, and soft fruits: Characterization of the method performances. Int. J. Food Microbiol. 117, 141-149 (2007).

26. Scherer, K., Johne, R., Schrader, C., Ellerbroek, L., Schulenburg, K. and Klein, G.: Comparison of two extraction methods for viruses in food and application in a norovirus gastroenteritis outbreak. J. Virol. Methods 169, 22-27 (2010).

27. Hernández, F.R., Monge, C. and Jiménez, C.: Taylor L. Rotavirus and hepatitis A virus in market lettuce (Latuca savita) in Costa Rica. Int. J. Food Microbiol. 37, 221-223 (1997).

28. Ward, B.K., Chenoweth, C.M. and Irving, L.G.: Recovery of viruses from vegetable surfaces. Appl. Environ. Microb. 44, 1389-1394 (1982).

29. Shinohara, M., Uchida, K., Shimada, S., Tonioka, K., Suzuki, N., Minegishi, T., Kawahashi, S., Yoshikawa, Y. and Ohashi, N.: Application of simple method using minute particles of amorphorus calcium phosphate for recovery of norovirus from cabbage, lettuce, and ham. J. Virol. Methods 187, 153-158 (2013).

30. Schwab, K.J., Neill, F.H., Fankhauser, R.L., Daniels, N.A., Monroe, S.S., Bergmire Sweat, D.A., Estes, M. and Atmar, R.L.: Development of methods to detect 'Norwalk-like viruses' (NLVs) and hepatitis A virus in delicatessen foods: application to a food-borne NLV outbreak. Appl. Environ. Microbiol. 66, 213-218 (2000).

31. Leggitt, P.R. and Jaykus, L.A.: Detection methods for human 
292 Aerie Moon, Jaehyun Ahn, and Weon Sang Choi

enteric viruses in the representative foods. J. Food Protect. 63, 1738-1744 (2000).

32. Rueckert, R.R.: Picornaviridae: The viruses and their replication. In: Fields Virology. Fields BN, Knipe DM, Howley PM (eds). Lippincott-Raven Pub. Philadelphia, PA, USA, pp.
609-654 (1996)

33. Atmar, R.L., Neill, F.H., Romalde, J.L., Guyader, F.L., Woodley, C.M., Metcalf, T.G. and Estes, M.K.: Detection of Norwalk virus and hepatitis A virus in shellfish tissues with the PCR. Appl. Environ. Microbiol. 61, 3014-3018 (1995). 